\title{
Recombinant Human Retinol-Binding Protein Refolding, Native Disulfide Formation, and Characterization
}

\author{
Yansheng Xie, Hilal A. Lashuel, Greta J. Miroy, Sergei Dikler, and J effery W. Kelly ${ }^{1}$ \\ Department of Chemistry and the Skaggs Institute of Chemical Biology, The Scripps Research Institute, \\ 10550 North Torrey Pines Road, MB12, La J olla, California 92037
}

Received May 8, 1998, and in revised form J une 14, 1998

\begin{abstract}
Human retinol-binding protein (RBP) is a monomeric 21-kDa protein that is currently the subject of numerous studies owing to its role in the cellular uptake and utilization of retinol. When the RBP gene is overexpressed in Escherichia coli, inclusion bodies of aggregated RBP are found in the cells. These inclusion bodies are solubilized in 5.0 M GdmCl containing $10 \mathrm{mM}$ DTT. Refolding of RBP is carried out in the presence of vitamin A by diluting denatured and reduced $R B P$ into a redox refolding buffer consisting of $3 \mathrm{mM}$ cysteine/ $0.3 \mathrm{mM}$ cystine at $4^{\circ} \mathrm{C}$. Ion exchange chromatography (HPLC) is utilized to purify refolded RBP to homogeneity as demonstrated by SDS-PAGE and electrospray MS. The native structure of refolded RBP was established by its ability to bind to vitamin $A$ and the plasma protein transthyretin. The reconstitution of RBP outlined within affords a $50-60 \%$ overall yield, i.e., $73 \mathrm{mg}$ of pure RBP/L of E. coli culture. $\odot 1998$ Academic Press
\end{abstract}

The development of recombinant DNA methodology has led to a revolution in protein production for both research and industrial applications (1). Through overexpression of genes engineered into eukaryotic and prokaryotic cells, it is now possible to produce significant quantities of rare, high-value proteins which are inaccessiblethrough conventional purification procedures. However, it is not unusual for proteins undergoing prokaryotic expression to aggregate into "inclusion bodies" as a result of the self-assembly of protein folding intermediates (2-4). Inclusion body dissociation and solubilization as well as protein refolding is still a semiempirical process, due to the numerous variables that are manipulated to recover folded proteins (5-12).

Understanding protein folding is by itself a matter of both intrinsic and practical interest, owing in part to

\footnotetext{
${ }^{1}$ To whom correspondence should be addressed. E-mail jkelly@scripps. edu. Fax: (619)784-9610.
}

the dream that someday tertiary structure can be predicted from sequence data (13). Protein refolding is generally accepted to be a spontaneous process under suitable conditions, directed by the protein's linear amino acid sequence and the aqueous refolding environment (14). Reconstitution is affected by competitive kinetic processes, whose activation barriers can be manipulated by changing experimental variables including protein concentration, denaturant concentration, temperature, redox potential, $\mathrm{pH}$, and ligand concentration. Aggregation resulting from the self-assembly of folding intermediates competes with intramolecular refolding, and hence it is not surprising that in many cases protein reconstitution leads to a disappointingly Iow yield of active protein $(3,15,16)$. Refolding experiments are typically performed at low protein concentrations $(\mu \mathrm{g} / \mathrm{mL})$ to avoid aggregation. However, the refolding of active proteins from dilute chaotropic solutions is not very practical or cost-effective when large quantities of a protein are needed. Optimization of the refolding of human $\mathrm{RBP}^{2}$ is described within, allowing reconstitution to be carried out at a modest concentration of $0.25 \mathrm{mg} / \mathrm{mL}$.

Human plasma retinol-binding protein binds to one equivalent of vitamin $A$ and is one of the major retinol carriers found in the blood plasma of mammals (17). Human RBP is a monomeric $21-k D a ~ \beta$-sheet-rich protein that is stabilized by three disulfide bonds. In plasma, RBP typically forms a 1:1 complex with tetrameric transthyretin (TTR, $54 \mathrm{kDa}$ ) which prevents RBP from being removed from the plasma by glomerular filtration. It is difficult to purify RBP from blood owing to its affinity for

\footnotetext{
${ }^{2}$ Abbreviations used: CAPS, 3-cyclohexylamine-1-propanesulfonic acid; DTT, dithiothreitol; EDTA, ethylenediaminetetraacetic acid; $\mathrm{GdmCl}$, guanidinium chloride; GSH, glutathione; GSSG, oxidized glutathione; MW, molecular weight; NHS, N-hydroxysuccinimide; PAGE, polyacrylamide gel electrophoresis; PBS, phosphate-buffered saline; PMSF, phenylmethylsulfonyl fluoride; RBP, retinol-binding protein; TTR, transthyretin; SDS, sodium dodecyl sulfate.
} 
TTR, and its heterogeneity (18). The genetics of RBP have been studied extensively and its CDNA sequence determined, making recombinant expression feasible (19). An efficient expression system for RBP has been constructed using the $\mathrm{pET3a}$ vector which yields RBP inclusion bodies (20). Here we report a rational refolding protocol for recovering functional RBP from inclusion bodies that consists of two basic steps: (a) solubilization and reduction of RBP indusion bodies and (b) redox refolding of the denatured/reduced RBP in the presence of vitamin $A$. Refolding results in a $\sim 55 \%$ yield of properly folded and biologically active RBP.

\section{MATERIALS AND METHODS}

Chemicals and instrumentation. Cysteine, cystine, EDTA, and Trizma-base are purchased from Sigma Co. (St. Louis, MO). Ultrapure guanidinium chloride is from Schwartz/Mann Biotech of ICN (Cleveland, $\mathrm{OH}$ ). NHS-activated Sepharose medium (prepacked) is from Pharmacia Biotech. The protein assay reagent Coomassie Plus is from Pierce Co. Other reagents used are molecular biology grade.

Expression of RBP in E. coli and solubilization of RBP. The E. coli expression system for RBP has been described previously by Wang et al. (20). The culture volumes were increased in our experiments to $6 \times 1.5$ $\mathrm{L}$ (9 $\mathrm{L}$ total). The 1.5-L cultures in LB media were inoculated with $5 \mathrm{~mL}$ of an overnight culture and grown in shake flasks at $37^{\circ} \mathrm{C}$. When the optical density of the 1.5-L culture increased to an absorbance of $0.6 \sim 0.8$ at $600 \mathrm{~nm}, 1.5 \mathrm{~mL}$ of $1.0 \mathrm{M}$ IPTG was added to each shake flask to induce the production of RBP. After $8 \mathrm{~h}$, the cells were harvested at $7500 \mathrm{rpm}(15 \mathrm{~min})$ in a preparative centrifuge at $4^{\circ} \mathrm{C}$. The combined pellets were then washed with $1.0 \mathrm{~L}$ of $0.9 \% \mathrm{NaCl}$ and resuspended in $1.0 \mathrm{~L}$ of $50 \mathrm{mM}$ Tris, $2 \mathrm{mM}$ EDTA, $2 \mathrm{mM}$ PMSF, $0.1 \%$ Triton $\mathrm{X}-100(\mathrm{pH}$ 7.5). The cell suspension was sonicated for $1 \mathrm{~min}$ and freeze-thawed twice. The resulting suspension was centrifuged at $10,000 \mathrm{rpm}$ (15 $\mathrm{min}$ ) in a preparative centrifuge at $4^{\circ} \mathrm{C}$. As shown by SDS-PAGE (Fig. 2), RBP was again found in the pellet (inclusion bodies). The RBP inclusion bodies were pooled and suspended (partially dissolved) in 160 $\mathrm{mL}$ of $7.5 \mathrm{M} \mathrm{GdmCl}$ (7.5 M GdmCl stock solution concentration determined with an Abbe refractometer according to Nozaki (21)). The final volume of denatured RBP suspension was diluted to $240 \mathrm{~mL}$ with $25 \mathrm{mM}$ Tris buffer, $\mathrm{pH} 9.0$, to make the final $\mathrm{GdmCl}$ concentration $5.0 \mathrm{M}(\sim 5 \mathrm{mg} / \mathrm{mL}$ RBP in the suspension at this point of which $2 \mathrm{mg} / \mathrm{mL}$ RBP is soluble; Fig. 1). Fiftymilliliter aliquots of the denatured RBP stock suspension in $5 \mathrm{M} \mathrm{GdmCl}$ are taken and diluted to $200 \mathrm{~mL}$ with $5.0 \mathrm{M} \mathrm{GdmCl}$. To achieve reduction and further solubilization, $0.308 \mathrm{~g}$ of DTT is added to the suspension and final $\mathrm{pH}$ is adjusted to 9.0 for reduction at $25^{\circ} \mathrm{C}$ with vigorous mechanical stirring (overnight). The total protein concentration at this point is $\sim 2.5$ $\mathrm{mg} / \mathrm{mL}$ as determined by Coomassie binding (22). Half of the protein in the denatured and reduced stock solution is RBP $(\sim 1.25 \mathrm{mg} / \mathrm{mL})$.

Oxidativer fol ding. The oxidative refolding of RBP is carried out by dilution of the denatured and reduced stock solution of RBP $(1.25 \mathrm{mg} / \mathrm{mL})$ into a redox refolding buffer containing a 10-fold molar excess of vitamin A, yielding a final RBP concentration of $0.25 \mathrm{mg} / \mathrm{mL}$. To initiate refolding, 1 vol (typically $100 \mathrm{~mL}$ ) of $\sim 1.25$ $\mathrm{mg} / \mathrm{mL}$ denatured and reduced RBP in $5.0 \mathrm{M} \mathrm{GdmCl}$ is rapidly mixed with 4 vol of the redox refolding buffer containing vitamin $\mathrm{A}$, while magnetic stirring the solution vigorously (final $[\mathrm{GdmCl}]=1.0 \mathrm{M}$ ). The refolding solution should be kept in an ice bath or cold room for $5 \mathrm{~h}$ after refolding is initiated. Refolding RBP in the absence of vitamin A affords a poor yield of properly folded RBP $(\sim 20 \%)$. Theredox refolding buffer is composed of $0.3 \mathrm{mM}$ cystine, $3 \mathrm{mM}$ cysteine, $1 \mathrm{mM}$ EDTA, $25 \mathrm{mM}$ Tris- $\mathrm{HCl}$ buffer ( $\mathrm{pH}$ 9.0), and is degassed by nitrogen sparging for $20 \mathrm{~min}$. After degassing, $3.2 \mathrm{~mL}$ of $15 \mathrm{mM}$ retinol (dissolved in ethanol under argon) is added to the redox diluting buffer right before adding denatured RBP. To avoid aggregation, all solutions were prechilled in an ice bath or in cold room before combining the refolding buffer with denatured RBP at $4^{\circ} \mathrm{C}(23)$.

RBP purification. After refolding, the RBP solution was desalted by ultrafiltration employing an Amicon concentrator ( PM10 membrane) by several additions of the $25 \mathrm{mM}$ Tris- $\mathrm{HCl}$ buffer, $\mathrm{pH} 8.0$ (final volume $80 \sim 100 \mathrm{~mL}$ ). A Waters 8HR15 DEAE ion exchange column was used to purify the refolded RBP protein. Because of minor protease contamination, the separation should be done as soon as desalting is completed to avoid RBP degradation (alternatively 2 mM PMSF was added). Typically, $25 \mathrm{~mL}$ of concentrated refolded RBP (containing about $25 \mathrm{mg}$ of total protein) is loaded onto the Waters 8HR 15 DEAE column, in $25 \mathrm{mM}$ Tris- $\mathrm{HCl}$ buffer, pH 8.0. RBP is eluted from the column by a $\mathrm{NaCl}$ gradient at $0.12 \mathrm{M}(0$ to $0.30 \mathrm{M}$ gradient employed over $40 \mathrm{~min}$ ). The UV detector was set at 330 $\mathrm{nm}$ (retinol absorbance to allow the collection of only correctly refolded RBP bound to one molecule of retinol (extinction coefficient of RBP at $280 \mathrm{~nm}=2.02$ and $1.74 \mathrm{~mL} \cdot \mathrm{mg}^{-1} \cdot \mathrm{cm}^{-1}$ for RBP :retinol and apoRBP, respectively (24)).

Affinity chromatography. An RBP affinity column was prepared by covalently linking transthyretin (extinction coefficient at $280 \mathrm{~nm}=1.34 \mathrm{~mL} \cdot \mathrm{mg}^{-1} \cdot \mathrm{cm}^{-1}$ in $10 \mathrm{mM}$ phosphate buffer, $150 \mathrm{mM} \mathrm{KCl}, \mathrm{pH} 7.5$ (18)) to a Pharmacia NHS-activated Sepharose prepacked column according to the instructions from Pierce Co. Pure recombinant TTR (10 mg), prepared and purified as described by McCutchen et al. (25), was used for the 
preparation of this column. To demonstrate that refolded RBP would bind to Sepharose-linked TTR with high affinity, $400 \mu \mathrm{L}$ of HPLC-purified RBP (1.0 mg/ $\mathrm{mL}$ ) was injected onto the TTR affinity column in 10 $\mathrm{mM}$ phosphate, $150 \mathrm{mM} \mathrm{KCl}, \mathrm{pH} 7.5$ buffer (330 nm detection (RBP-vitamin A complex)). After washing the column with copious quantities of injection buffer (10 mM phosphate, $150 \mathrm{mM} \mathrm{KCl,} \mathrm{pH} \mathrm{7.5),} \mathrm{it} \mathrm{was} \mathrm{clear}$ that RBP was bound to the TTR column. The mobile phase was then changed to $1 \mathrm{mM}$ CAPS buffer (pH 10) which eluted RBP, as was the case for RBP isolated from plasma.

Analytical ultracentrifugation analysis of RBP-TTR binding. In a typical experiment, a sample solution containing $0.38 \mathrm{mg} / \mathrm{mL}$ RBP and $1.01 \mathrm{mg} / \mathrm{mL}$ TTR in PBS buffer is preincubated overnight. The sample (400 $\mu \mathrm{L}$ ) was then subjected to sedimentation velocity experiments with pure RBP and TTR protein solutions being used as controls. Sedimentation velocity data were collected on a temperature-controlled Beckman XL-A analytical ultracentrifuge with a An60Ti rotor and photoelectric scanner. A double sector cell equipped with a 12-mm E pon centerpiece and Sapphire windows was loaded with $400 \sim 420 \mu \mathrm{L}$ of solution using a blunt-end microsyringe. Data were collected in a continuous mode at $20^{\circ} \mathrm{C}$, employing a step size of $0.005 \mathrm{~cm}$, an average of four scans/point, and at a rotor speed of 3000-60,000 rpm. The data were analyzed using both the second moment boundary sedimentation analysis and the $d d d t$ time derivative analysis for calculating the apparent sedimentation coefficient distribution $\left(g\left(s^{*}\right)\right)$ for sedimenting species $(26,27)$.

\section{RESULTS}

The solubilization of inclusion bodies is usually carried out by adding concentrated $\mathrm{GdmCl}$ to the pellets, resulting in a final $\mathrm{GdmCl}$ concentration of $5.0 \sim 6.0$ $\mathrm{M}$. However, a large portion of the RBP inclusion bodies remains insoluble in $5.0 \mathrm{M} \mathrm{GdmCl}$ even after prolonged stirring. After centrifugation at $12,000 \mathrm{rpm}$ for $15 \mathrm{~min}$, the soluble denatured RBP concentration was determined to be $40 \%$ of the total RBP present in the suspension (Fig. 1). A nonreducing SDS gel experiment (no reducing agent in sample buffer) demonstrates that approximately $60 \%$ of RBP stays in the bottom of the sample well, incapable of entering the gel, consistent with a misfolded intermolecular S-S-linked aggregate (data not shown). The solubilization of RBP was improved 2.5-fold by adding $10 \mathrm{mM}$ DTT to the $5.0 \mathrm{M} \mathrm{GdmCl}, 25 \mathrm{mM}$ Tris- $\mathrm{HCl}$ buffer, $\mathrm{pH}$ 9, solubilization solution. As a result of reduction and denaturation, the majority of the RBP inclusion bodies were dissolved, increasing the reduced and denatured RBP concentration by $250 \%$ relative to simply employing 5.0 M GdmCl (Fig. 1).

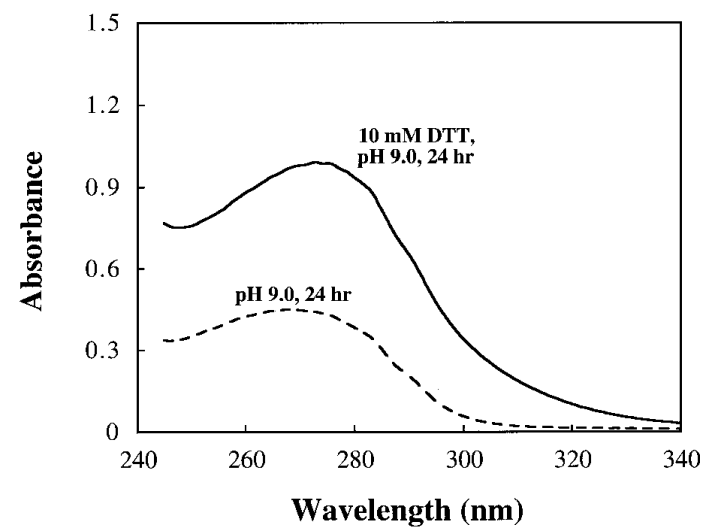

FIG. 1. The solubilization of RBP inclusion bodies with and without DTT reduction. The upper curve represents the 2.5 -fold increase in RBP concentration afforded when reduction and denaturation are employed. The lower curve represents the lower solubilization effected by denaturant in the absence of a reducing agent. The UV spectra were obtained by 20 -fold dilution of $1.0 \mathrm{~mL}$ of suspension of the inclusion bodies in $5.0 \mathrm{M} \mathrm{GdmCl}$ using $5.0 \mathrm{M} \mathrm{GdmCl}$ in $25 \mathrm{mM}$ Tris buffer, $\mathrm{pH}$ 9. Solid DTT is added to half the samples yielding a final DTT concentration of $10 \mathrm{mM}$. Aliquots from the reduced and nonreduced samples were spin filtered using $0.45-\mu \mathrm{m}$ microfiltration tubes yiel ding the samples used to record the UV spectra. Representative spectra are shown in Figure 1.

The pioneering work of Saxena and Wetlaufer (28) and Wetlaufer et al. (29) was adapted to make an effective redox buffer composed of $3 \mathrm{mM}$ cysteine, 0.3 $\mathrm{mM}$ cystine, $1 \mathrm{mM}$ EDTA to facilitate the formation of the three native disulfide bonds. The RBP concentration during refolding was optimized to be $0.25 \mathrm{mg} / \mathrm{mL}$, giving a satisfactory refolding yield of $50 \sim 60 \%$ in the presence of a 10-fold excess of vitamin A. To control the aggregation of refolding RBP, the reduced and denatured RBP solution as well as the oxidative refolding/ dilution buffer must be prechilled to $4^{\circ} \mathrm{C}$ in an ice-bath, or preequilibrated in a cold room before refolding commences (23). The refolding solution was kept at $4^{\circ} \mathrm{C}$ for $5 \mathrm{~h}$, allowing refolding and disulfide formation/reshuffling to proceed to completion before the RBP solution is desalted for purification. A desalting procedure employing ultrafiltration using an Amicon concentrator is preferred for its speed which minimizes degradation of RBP presumably caused by protease contamination. The presence of vitamin A (the physiological ligand of RBP) in the refolding buffer is very important to help RBP achieve its native structure through refolding. In the absence of vitamin A, properly folded apoRBP could be obtained after purification, but only in a low yield $(\approx 20 \%)$, making purification difficult. Typically, the yield of this refolding procedure is $50 \sim 60 \%$ for a 100-mg scale RBP preparation in the presence of vitamin A (Table 1).

After desalting, refolded RBP reconstituted in the presence of vitamin $A$ is purified on a DEAE-column (HPLC), eluting with $25 \mathrm{mM}$ Tris- $\mathrm{HCl}$ buffer, $\mathrm{pH} 8.0$, with a $\mathrm{NaCl}$ 
XIE ET AL.

TABLE 1

Yield for the Solubilization, Refolding, and Purification of $125 \mathrm{mg} / 1200 \mathrm{mg}$ of RBP Inclusion Bodies

\begin{tabular}{|c|c|c|c|c|}
\hline Purification step & Total protein (mg) & RBP (mg) & RBP purity (\%) & RBP yield (\%) \\
\hline RBP inclusion body solubilizationa & 250 & 125 & 50 & $100^{\mathrm{b}}$ \\
\hline DEAE chromatography after RBP refolding ${ }^{c}$ & 86 & 69 & 99 & $55^{d}$ \\
\hline
\end{tabular}

a Total protein concentrations were determined by Coomassie binding. Approximately 1200 mg of RBP inclusion bodies was obtained from $9 \mathrm{~L}$ of cell culture ( $\sim 30 \mathrm{~g}$ of cells, wet weight); however, only a 125-mg portion was used in each refolding experiment due to the volume of solution required for reconstitution.

$\mathrm{b}$ The percentage of RBP was calculated based on the amount of soluble monomeric RBP recovered after each step. Reduction is required to get complete solubilization of RBP (see text).

CTotal protein concentrations were determined by Coomassie binding and RBP concentrations were determined by UV absorbance at 280 $\mathrm{nm}$ after purification.

${ }^{d}$ Refolding RBP in the absence of vitamin A affords a poor yield ( $\left.\sim 20 \%\right)$ of properly folded RBP, which is very difficult to separate from improperly folded protein.

salt gradient. The RBP protein was purified to homogeneity, as discerned by SDS-PAGE (Fig. 2). The UV spectrum of the RBP-vitamin A complex gives the characteristic double maximum at 280 and $330 \mathrm{~nm}$, with a ratio of peak heights of ca. 1:1 (Fig. 3). The RBP-vitamin A UV spectrum suggests that refolded RBP has gained the native structure, as RBP refolded without vitamin A afforded only a weak maximum at $330 \mathrm{~nm}$, reflecting the fact that most of the apoRBP could not bind vitamin A. N-terminal amino acid sequencing of purified RBP yields the expected sequence, MERDXRVSSF. The molecular weight determined by electrospray mass spectrometry reveals a molecular mass of $21,202.8$, which matches exactly with the calculated value from the RBP sequence assuming three disulfide bonds (21,202.8; Fig. 4). These data provide strong evidence that the refolded RBP has the intact sequence and the three expected disulfide linkages.

When RBP is injected onto an affinity column with transthyretin covalently attached and washed with PBS buffer, RBP exhibits strong binding to the TTR column (Fig. 5). Retinol-binding protein is eluted upon changing

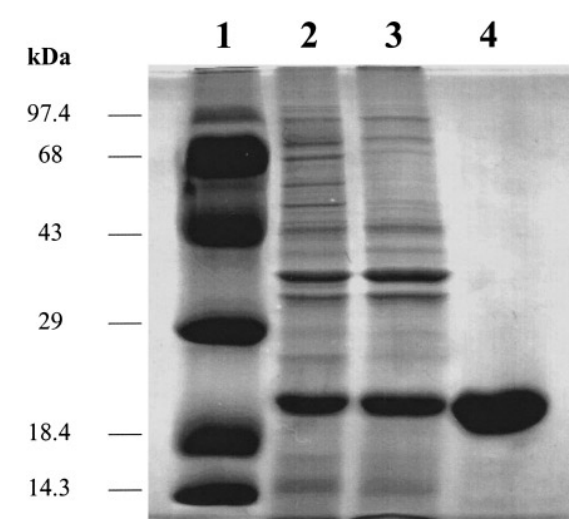

FIG. 2. SDS-PAGE of RBP samples stained with Coomassie blue G-250. Lane 1, molecular weight standard; lane 2, cell lysate; lane 3, solubilized and reduced inclusion bodies; lane 4, refolded RBP after HPLC purification. Each lane was loaded with $10 \mu \mathrm{g}$ total protein. the buffer to $1 \mathrm{mM}$ CAPS, pH 10, identical to the results obtained with RBP isolated from human plasma. To further investigate the TTR-binding properties of refolded RBP, analytical ultracentrifugation was employed to characterize the solution behavior of the RBP-TTR complex. Pure RBP and TTR solutions exhibit sedimentation coefficients of 2.0 and $4.2 \mathrm{~s}$, consistent with their molecular weights of 21,000 and 54,000, respectively. However, analysis of the RBP-TTR complex reveals a predominant species with a sedimentation coefficient of $5.6 \mathrm{~s}$ (MW $75,000)$, consistent with the mass of the RBP-TTR complex (Figs. 6A, 6B).

\section{DISCUSSION}

Protein refolding is still regarded as challenging and difficult, particularly for many multidomain or highly

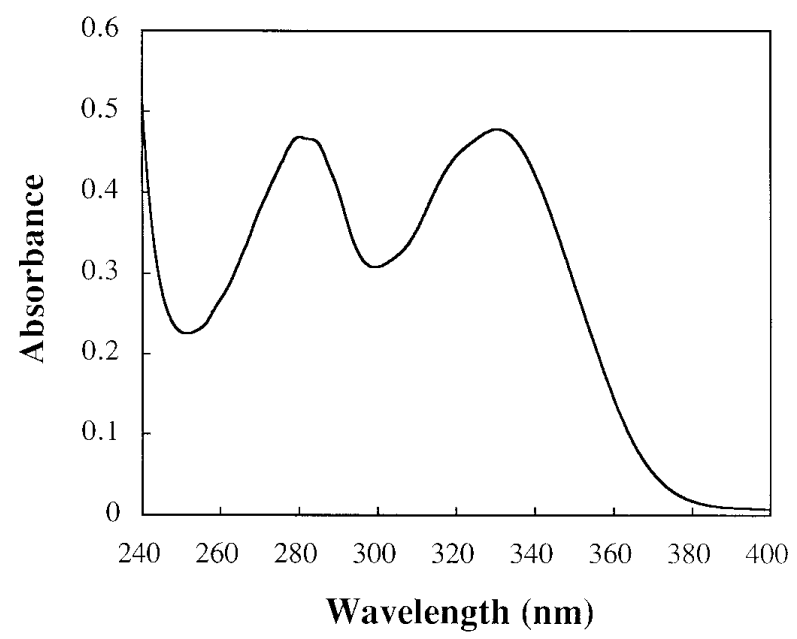

FIG. 3. UV spectrum of the human retinol binding protein:retinol complex. The sample was prepared by refolding the denatured and reduced RBP from 5.0 M GdmCl, in the presence of 10-fold excess of vitamin A (see Materials and Methods for details). The UV spectrum of RBP:retinol complex was obtained after purification, with a protein concentration of $0.23 \mathrm{mg} / \mathrm{mL}$ in PBS. 


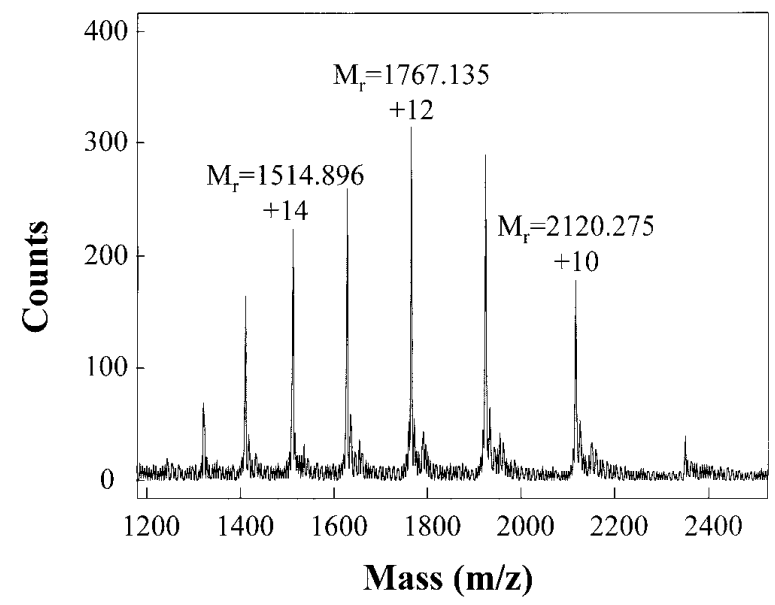

FIG. 4. Electrospray mass spectrum of refolded RBP. A solution of $0.5 \mathrm{mg} / \mathrm{mL}$ refolded RBP (in PBS) was rapidly desalted using a Sephadex G-25 column (prepacked from Pharmacia). The RBP was sent for electrospray mass spectrometry measurement within a few hours after desalting.

disulfide-crosslinked proteins. The expression of human proteins in E. coli often results in inclusion body formation. Inclusion bodies are typically dissolved under strongly denaturing conditions ( $\mathrm{GdmCl}$, urea), and the denaturant diluted to allow protein refolding to occur. However, this traditional approach is problematic due to aggregation stabilized by intermolecular disulfide bonds between folding intermediates. In this study, we utilized denaturation and reduction followed by refolding facilitated by dilution into a redox buffer in the presence of RBP's native ligand to promote efficient refolding. This paper and previous studies demonstrate that a number of factors can be varied to achieve refolding at higher protein concentrations $(0.25 \mathrm{mg} / \mathrm{mL})$ and in high yields by varying the denaturant concentration, redox buffer composition, temperature, and ligand concentration (2).

Aggregation in some cases competes efficiently with intramolecular folding $(30,31)$, particularly at higher protein concentration. Significant effort has been devoted to reducing aggregation during refolding with some success utilizing various surfactants and additives like arginine in the refolding solution (32). Through numerous experiments, it is now widely accepted that the early folding intermediates aggregate largely through hydrophobic interactions. By taking advantage of low temperature to attenuate the hydrophobic effect, a rational method of "temperature modulation" has been used for controlling aggregation and achieving good reconstitution yields (23). The refolding strategy for a given protein should be designed on the basis of its folding kinetics, where the conditions are optimized experimentally. For RBP refolding, the protein concentration was optimized to be $0.25 \mathrm{mg} / \mathrm{mL}$, with a $\mathrm{GdmCl}$ concentration of $1.0 \mathrm{M}$ in $25 \mathrm{mM}$ Tris$\mathrm{HCl}$ buffer, pH 9.0.

When recombinant proteins with multidisulfide bonds are expressed in inclusion bodies, the formation of intermolecular (interchain) disulfide bonds makes the inclusion body pellets largely insoluble even in strong denaturant solutions (see Fig. 1) (33). For efficient solubilization of recombinant RBP, it is necessary to reduce these intermolecular disulfide bonds employing the reducing reagent dithiothreitol (DTT) (34). The $\mathrm{pH}$ of denatured protein solution is typically adjusted to 9.0 to increase the thiol/disulfide exchange rate by raising the concentration of thiolate anions ( $\left.\mathrm{pK}_{a} 8-10\right)$. It has been shown that the inclusion of 10 mM DDT in $\mathrm{GdmCl}$ solution is sufficient to reduce the RBP inclusion bodies under slightly alkaline conditions, resulting in a 2.5-fold increase in dissolved reduced and denatured RBP (Fig. 1).

The folding pathway exhibited by a denatured and reduced protein is typically complex and sometimes difficult to decipher in detail (35-40). It is well-known that the refolding of denatured/reduced proteins can be accomplished by employing a so-called "redox shuffling" buffer $(28,41-44)$. These oxidative refolding systems usually consist of low-molecular-weight thiols and disulfides, such as GSH/GSSG or cysteine/cystine, and have been used extensively for controlling protein disulfide formation. These systems offer several advantages over air auto-oxidation as they increase the yield of renaturation and re-oxidation by facilitating rapid reshuffling of incorrect disulfide bonds ultimately yielding in many cases native disulfides (45). In the preparative scale refolding of RBP, a cysteine/cystine

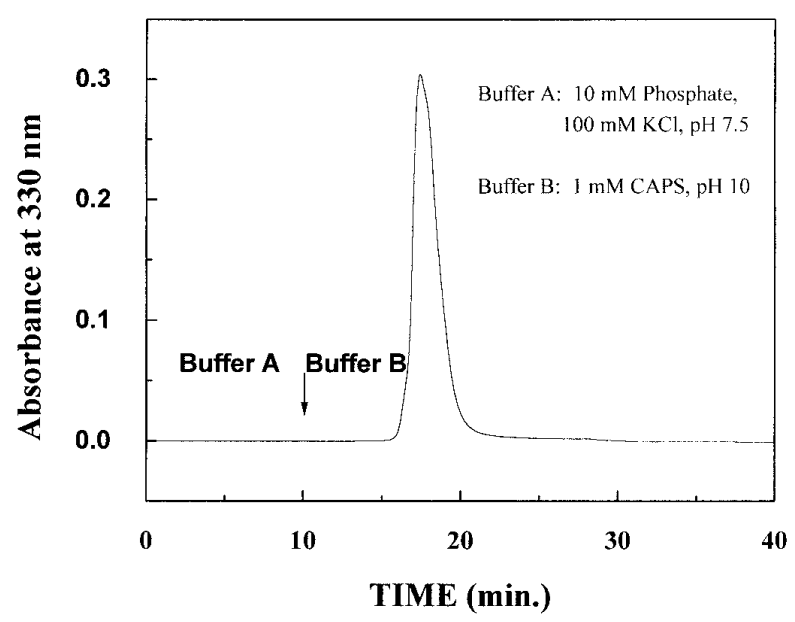

FIG. 5. Affinity chromatography of refolded RBP on TTR column prepared by coupling $10 \mathrm{mg}$ TTR to a 1-mL NHS-activated Sepharose medium. A refolded RBP sample ( $\sim 400 \mu \mathrm{g}$ purified by HPLC) was applied to the TTR affinity column, in $10 \mathrm{mM}$ phosphate, $150 \mathrm{mM}$ $\mathrm{KCl}$ buffer, pH 7.5. RBP was eluted by a $1 \mathrm{mM}$ CAPS buffer, $\mathrm{pH} 10$, after washing the column with $20 \mathrm{~mL}$ of PBS to elute the unbound proteins. 

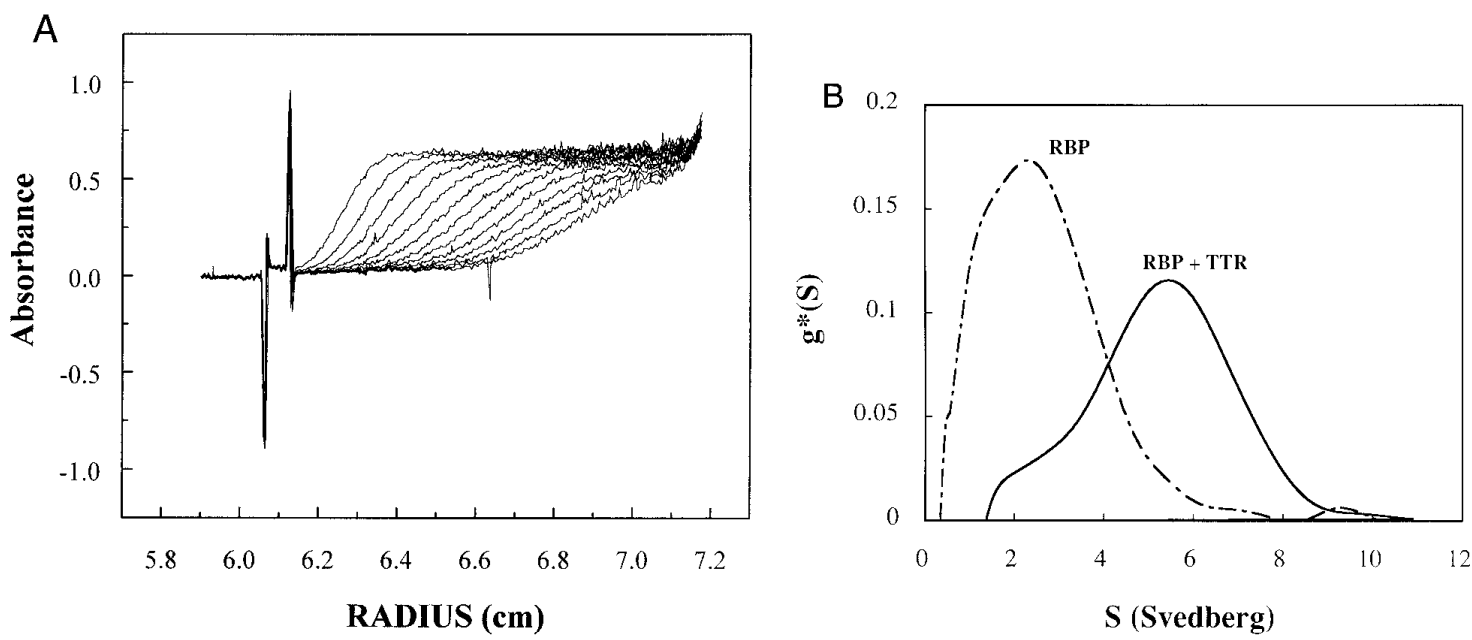

FIG. 6. (A) Sedimentation velocity analysis of RBP-TTR complex. A sample solution of $400 \mu \mathrm{L}$ containing $0.38 \mathrm{mg} / \mathrm{mL}$ refolded RBP and $1.01 \mathrm{mg} / \mathrm{mL}$ TTR was incubated overnight to achieve binding equilibrium. Then sample was subjected to vel ocity analysis in a Beckman XL-A analytical ultracentrifuge, using an An60Ti rotor at speeds from 3000 to 15,000 rpm. (B) Molecular weight analysis ((g)*s) of species in the RBP-TTR solution.

system is preferred owing to its efficacy and costeffectiveness.

The characteristic UV spectrum of the RBP-vitamin A complex (double maximum at 280 and $330 \mathrm{~nm}$ with approx. 1:1 intensity), in combination with the mass spectrometry data inidcating that the three disulfide bonds are intact, suggests that the native three-dimensional structure has formed. More importantly, refolded RBP is biologically active as demonstrated by its ability to bind vitamin A and transthyretin with properties strictly analogous to RBP isolated from human plasma. These results strongly support our contention that this method is effective for RBP refolding and native disulfide bond formation. The reconstitution of RBP outlined within affords a 50-60\% overall yield, i.e., $\approx 69 \mathrm{mg}$ of pure RBP out of $\approx 125 \mathrm{mg}$ of RBP inclusion bodies derived from $0.94 \mathrm{~L}$ of $\mathrm{E}$. coli culture (Table 1).

\section{ACKN O WLEDG MENTS}

We thank the National Institutes of Health (NIH DK46335-01), the Lita Annenberg Hazen Family, and the Skaggs Family for funding, Dr. Thomas T.Y. Wang for providing the PRBP/ET3a expression vector (20) and Professors Donald B. Wetlaufer and Hiram F. Gilbert for their constructive criticism and critical reading of this paper.

\section{REFERENCES}

1. Itakura, K., Hirose, T., Crea, R., Riggs, A. D., Heyneckker, H. L., Bolivar, F., and Boyer, H. W. (1977) Expression in Escherichia coli of a chemically synthesized gene for the hormone somatostatin. Science 198, 1056-1063.

2. Rudolph, R., and Lilie, H. (1996) In vitro folding of inclusion body protein. FASEB J . 10, 49-56.

3. Wetzel, R. (1996) For protein misassembly, it is the "I" decade. Cell 86, 699-702.
4. Marston, F. A. O. (1986) The purification of eukaryotic polypeptides synthesized in Escherichia coli. Biochem. J . 240, 1-12.

5. Cleland, J . L. (Ed.) (1993) Protein Folding in Vivo and in Vitro, Vol. 526, American Chemical Society, Washington, DC.

6. Georgiou, G., and De Benadez-Clarke, E. (1991) Protein Refolding, Vol. 470. American Chemical Society, Washington, DC.

7. Valax, P., and Georgiou, G. (1993) Characterization and refolding of beta-lactamase inclusion bodies in Escherichia coli. ACS Symp. Ser. 516, 126-139.

8. Chrunyk, B. A., Evans, J ., and Wetzel, R. (1993) Probing the role of protein folding in inclusion body formation. ACS Symp. Ser. 526, 46-58.

9. Chaudhuri, J. B. (1994) Refolding recombinant proteins-protein chemistry vs. process engineering. Prog. Biotechnol. 9, 107110.

10. Georgiou, G., Valax, P., Ostermeier, M., and Horowitz, P. M. (1994) Folding and aggregation of TEM beta-lactamase: Analogies with the formation of inclusion bodies in Escherichia coli. Protein Sci. 3, 1953- 1960.

11. Middel berg, A. P. J . (1996) Large-scale recovery of recombinant protein inclusion bodies expressed in Escherichia coli. J . Microbiol. Biotechnol. 6, 225-231.

12. Thatcher, D. R., Wilks, P., and Chaudhuri, J . (1996) Inclusion Bodies and refolding. in Proteins Labfax. Academic Press, San Diego.

13. Skolnick, J ., Kolinski, A., Brooks, C. L., III, Godzik, A., and Rey, A. (1993) A method for predicting protein structure from sequence. Curr. Biol. 3, 414- 423.

14. Anfinsen, C. B. (1973) Principles that govern the folding of protein chains. Science 181, 223-230.

15. Wetzel, R. (1992) Protein aggregation in vivo. Bacterial inclusion bodies and mammalian amyloid. Pharm. Biotechnol. 3, 43- 88.

16. Wetzel, R. (1994) Mutations and off-pathway aggregation of proteins. Trends Biotechnol. 12, 193-198.

17. Goodman, D. (1994) The Retinoids: Biology, Chemistry, and Medicine. Raven Press, New York.

18. Peterson, P. A. (1971) Characteristics of a vitamin A transport- 
ing protein complex occuring in human serum. J. Biol. Chem. 246, 34- 43.

19. Colantuoni, V., Romano, V., Bensi, G., Santoro, C., Costanzo, F., Raugei, G., and Cortese, R. (1983) Cloning and sequencing of a full length cDNA coding for human retinol-binding protein. Nucleic Acids Res. 11, 7769-7776.

20. Wang, T. Y., Lewis, K. C., and Phang, J . M. (1993) Production of human plasma retinol-binding protein in Echerichia coli. Gene 133, 291-294.

21. Nozaki, Y. (1972) The preparation of guanidine hydrochloride. Methods Enzymol. 26, 43-50.

22. Bradford, M. M. (1976) A rapid and sensitive method for the quantitation of microgram quantities of protein utilizing the principle of protein dye binding. Anal. Biochem. 72, 248-254.

23. Xie, Y., and Wetlaufer, D. B. (1996) Control of aggregation in protein refolding: The temperature-leap tactic. Protein Sci. 6, 517-523.

24. Bychkova, V. E., Berni, R., Rossi, R. L., Kutyshenko, V. P., and Ptitsyn, O. B. (1992) Retinol-binding protein is in the molten globule state at low pH. Biochemistry 31, 7566-7571.

25. McCutchen, S., Colon, W., and Kelly, J . W. (1993) Transthyretin mutation Leu-55-Pro significantly alters tetramer stability and increases amyloidogenicity. Biochemistry 32, 12119-12127.

26. Stafford, W. F. (1994) Boundary analysis in sedimentation experiments. Methods Enzymol. 240, 478-450.

27. Stafford, W. F. (1992) Boundary analysis in sedimentation transport experiments: A procedure for obtaining sedimentation coefficient distributions using the time derivative of the concentration profile. Anal. Biochem. 203, 295-301.

28. Saxena, V. P., and Wetlaufer, D. B. (1970) Formation of threedimensional structure in proteins. I. Rapid nonenzymic reactivation of reduced lysozyme. Biochemistry 9, 5015-5023.

29. Wetlaufer, D. B., Branca, P. A., and Chen, G. X. (1987) The oxidative folding of proteins by disulfide plus thiols does not correlate with redox potential. Protein Eng. 1, 141-146.

30. Zettlmeissl, G., Rudolph, R., and J aenicke, R. (1979) Reconstitution of lactic dehydrogenase. Noncovalent aggregation vs. reactivation: I. Physical properties and kinetics of aggregation. Biochemistry 18, 5567-5571.

31. Cleland, J . L., and Wang, D. I. C. (1990) Refolding and aggregation of carbonic anhydrase B: Quasi-elastic light scattering analysis. Biochemistry 29, 11072-11078.
32. Wetlaufer, D. B., and Xie, Y. (1995) Control of aggregation in protein refolding: A variety of surfactants promote renaturation of carbonic anhydrase II. Protein Sci. 5, 1435-1443.

33. Schoemaker, J . M., Brasnett, A. H., and Marston, F. A. O. (1985) Examination of calf prochymotrypsin accumulation in Escherichia coli: Disulphide linkages are a structural component of prochymotrypsin-containing inclusion bodies. EMBO J . 4, 775780.

34. Cleland, W. W. (1964) Dithiothreitol, a new protective reagent for SH group. Biochemistry 3, 480- 482.

35. Creighton, T. E. (1992) The disulfide folding pathway of BPTI. Science 256, 111.

36. Creighton, T. E. (1988) Toward a better understanding of protein folding pathways. Proc. Natl. Acad. Sci. USA 85, 5082-5086.

37. Scheraga, H. A., Konishi, Y., and Ooi, T. (1984) Multiple pathways for regenerating ribonuclease A. Adv. Biophys. 18, 21- 41.

38. Wearne, S. F., and Creighton, T. E. (1988) F urthur experimental studies of the disulfide folding of ribonuclease A. Proteins 4, 251-261.

39. Weissman, J. S., and Kim, P. S. (1992) The disulfide folding pathway of BPTI-Response. Science 256, 112.

40. Weissman, J. S., and Kim, P. S. (1991) Reexamination of the folding of BPTI: Predominance of native intermediates. Science 253, 1386-1393.

41. Houk, J ., Singh, R., and Whitesides, G. M. (1987) Measurement of thiol-disulfide interchange reactions and thiol pKa values. Methods Enzymol. 143, 129-140.

42. Singh, R., and Whitesides, G. M. (1990) Comparisons of rate constants for thiolate-disulfide interchange in water and in polar aprotic solvents using dynamic proton NMR line shape analysis. J. Am. Chem. Soc. 112, 1190-7.

43. Singh, R., and Whitesides, G. M. (1990) Degenerate intermolecular thiolate-disulfide interchange involving cyclic five-membered disulfides is faster by $\sim 10^{3}$ than that involving six- or seven-membered disulfides. J . Am. Chem. Soc. 112, 6304- 6309.

44. Chivers, P. T., and Raines, R. T. (1997) General acid/base catalysis in the active site of Escherichia coli thioredoxin. Biochemistry 36, 15810-15816.

45. Gilbert, H. F. (1994) The formation of native disulfide bonds. In Mechanisms of Protein Folding (Pain, R. H., Ed.), pp. 104-136. IRL Press, Oxford, England. 